\title{
Communication
}

[Comunicação]

\section{Occurrence of Rhinoptericola megacantha (CESTODA, TRYPANORHYNCHA) in new host and new location}

[Ocorrência de Rhinoptericola megacantha (CESTODA, TRYPANORHYNCHA) em novo hospedeiro e nova localidade]

\author{
S.R. Napoleão ${ }^{1}$, A.M. Antonucci ${ }^{2}$, A.F. Amorim ${ }^{3}$, R.M. Takemoto $^{1,2}$
}

${ }^{1}$ Programa de pós-graduação - Patologia - Faculdade de Ciências Agrárias e Veterinárias, Universidade Estadual Paulista - Unesp - Campus Jaboticabal, SP

${ }^{2}$ Nupélia - Universidade Estadual de Maringá - UEM - Maringá, PR

${ }^{3}$ Pesquisador no Instituto de Pesca - IP - Santos, SP

The genus Rhinoptera, Cuvier, 1829, is represented by eight species of rays, distributed around the world. They are present in tropical, subtropical and warm-temperate waters, except around Oriental Pacific Island (Last and Stevens, 1994). Only two species occurred in Brazilian coast: the cownose ray Rhinoptera bonasus (Mitchill, 1815) and the ticon cownose ray $R$. brasiliensis (Muller, 1836) (Cavalcanti et al., 1997). These differentiate morphologically: $R$. bonasus usually has seven series of plates in both jaws, while $R$. brasiliensis teeth are typically arranged in series of nine (Bigelow and Schroeder, 1953). Rhinoptera brasiliensis is distributed from Rio de Janeiro to Rio Grande do Sul States, $23^{\circ}-32^{\circ} \mathrm{S}$ (Bigelow and Schroeder, 1953; Menni and Stehmann, 2000).

In trawls in the southern and southeastern Brazil, a significant portion of shrimp by-catch is discarded at sea, either by treating species without commercial value or juveniles of species of economic interest (D'incão et al, 2002). Some species from elasmobranch fishes are present in fishery shrimp by-catch (Lessa et. al, 1986; Voreen and Klippel, 2005), and many elasmobranchs are endangered due to the characteristics of slow growth, late sexual maturity and low fecundity (Stevens et al., 2000).

The actually status of Rhinoptera brasiliensis is "endangered", according to IUCN -Red List of Threatened Species, when the best available evidence indicates that it meets of the criteria for "endangered", and it is therefore considered to be facing a very high risk of extinction in the wild (Vooren and Lamónaca, 2013).

Studies about parasitological fauna of Brazilian elasmobranchs are rare. The aim of the present study was to report the first occurrence of Rhinoptericola megacantha in Rhinoptera brasiliensis, and the first occurrence of $R$. megacantha in Brazilian coast.

From April 2012 to April 2013 seven specimens of Rhinoptera brasiliensis were captured from shrimp fishery by-catch, Xiphopenaeus kroyeri, in southern and southeastern from Brazil. The specimens were found dead, and were stored in ice and taken to the laboratory to mensuration the mean length, mean width and mean weight.

The rays presented mean length $77(63-87.5) \mathrm{cm}$, mean width $65.5(61-70) \mathrm{cm}$ and mean weight $4.08(3.22-5.14) \mathrm{kg}$. All fish were necropsied at Instituto de Pesca de São Paulo (Santos, SP, Brazil), and stomach, heart, gills, liver and intestine were collected for study.

The organs were processed at the Universidade Estadual Paulista - Unesp (São Vicente, SP, Brazil).

The intestine of two rays were parasitized, and three specimens of cestoda Rhinoptericola megacantha (Cestoda, Trypanorhyncha) were 
collected in totally. Prevalence of infection $28 \%$, mean intensity 1.5 and mean abundance 0.43 , calculated according to Bush et al. (1997).

The cestodes were prepared for light microscopy being stained with acetic carmine and cleared with beechwood creosote. Permanent slide preparations used Canada balsam. Drawings were made with a drawing tube attached to a Nikon E200 microscope using contrast optics at Universidade Estadual de Maringá, UEM (Maringá, PR, Brazil). Type-specimens were deposited in Helminthological Collection of Instituto Oswaldo Cruz - IOC (Rio de Janeiro, RJ, Brazil).

The characteristics from Rhinoptericola megacantha: bothridia oval, arranged in pairs,

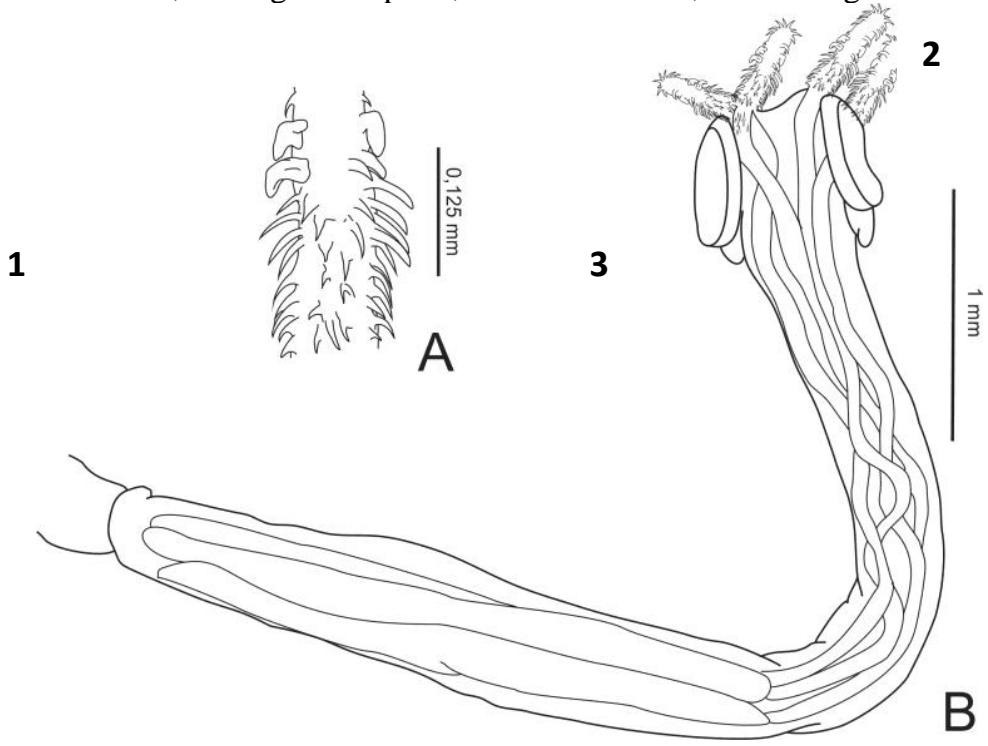

sessile and separated. Heteroacantha atypica. Scolex and tentacles long. The tentacles with five types of hooks. According to Call (2007), this characteristics differentiates $R$. megacantha from other cestodes of Rhinoptericolidae: Shirleyrhynchus aetobatidis (eight hooks) and Cetorhinicola acanthocapax (seven hooks). Rhyncheal apparatus well developed. Typica basal armature.

Measurements basead on two specimens: length $8.425 \mathrm{~mm}$, width $0.5 \mathrm{~mm}$; muscular: length $5.0 \mathrm{~mm}$, width $0.5 \mathrm{~mm}$, bothrio: length $0.56 \mathrm{~mm}$, width $0.36 \mathrm{~mm}$; scolex: width $0.72 \mathrm{~mm}$; length tentacles 2.8 - 3.03mm; first proglotid: length $0.624 \mathrm{~mm}$, width $0.292 \mathrm{~mm}$; gravid proglotid: length $0.890 \mathrm{~mm}$, width $0.750 \mathrm{~mm}$; testicle: width $0.014 \mathrm{~mm}$; hooks length: $0.045-0.052 \mathrm{~mm}$.

Figure 1. Drawing based in three specimens of Rhinoptericola megacantha (Cestoda, Trypanorhyncha), first collected in Rhinoptera brasilensis from Brazil. A: Basal armature: 1 - Tentacles with five types of hooks. B: Anterior extremity. 2 - Four tentacles partially externalized. 3 - Bothridia oval in pairs.

Rhinoptericola megacantha was firstly reported in Rhinoptera bonasus, caughted in Virginia, USA (Carvajal and Campbell, 1975).

It was reported in the same host in Gulf of Venezuela (Mayes and Brooks, 1980) and Gulf of Mexico (Call, 2007).

This is the first report on the occurrence of Rhinoptericola megacantha in Brazil and the first report in host Rhinoptera brasiliensis.
These data contribute to the knowledge of the parasitological fauna of rays in the Brazilian coast.

Keywords: Rhinoptera brasiliensis, Rhinoptericola megacantha, by-catch, elasmobranch, Brazil 


\section{RESUMO}

Relata-se a ocorrência de Rhinoptericola megacantha (Cestoda, Trypanorhyncha) parasitando duas raias da espécie Rhinoptera brasiliensis, de um total de sete espécimes analisados. Foram encontrados três espécimes do cestóide, que havia sido descrito ocorrendo apenas no hospedeiro Rhinoptera bonasus capturado em Virginia (EUA), Golfo Venezuelano e Golfo do México. Este é o primeiro relato da ocorrência de R. megacantha no hospedeiro R. brasiliensis e primeira ocorrência no Brasil deste cestóide.

Palavras-chave: Rhinoptera brasiliensis, Rhinoptericola megacantha, fauna-acompanhante, elasmobrânquios, Brasil

\section{REFERENCES}

BIGELOW, H. B; SCHROEDER, W. C. Sawfishes, guitarfishes, sharks and rays. In FISHES of the Western North Atlantic. New Haven: Sears Foundation for Marine Research, Yale University, 1953. Part two.

BUSH, J.O.; LAFFERTY, K.D.; LOTZ, J.M.; SHOSTAK, A.W. Parasitology meets ecology on its own terms: Margolis et al. revisited. J. Parasitol., v.83, p.575-583, 1997.

CALL, G. A survey of the tapeworm fauna of the cownose ray, Rhinoptera bonasus, from the northern Gulf of Mexico with comments on intermediate hosts. 2007. 141f. Thesis (MA) University of Kansas, Lawrence, Kansas, U.S.A.

CARVAJAL, J.; CAMPBELL, R.A. Rhinoptericola megacantha gen. et sp. n., representing a new family of trypanorhynch cestodes from the cownose ray, Rhinoptera bonasus (Mitchill 1815). J. Parasitol., v.61, p.1023-1030, 1975.

CAVALCANTI, M. J.; GALLO-DA-SILVA, V.; AFONSO A.F. Identificação de Rhinoptera bonasus (Mitchill, 1815) e $R$. brasiliensis Müller \& Henle, 1841 (Chondrichthyes, Myliobatiformes, Rhinopteridae) pela análise de funções discriminantes. Acta Biol. Leopold., v.19, p.205-215, 1997.

D'INCAO, F.; VALENTINI, H.; RODRIGUES, L.F. Avaliação da pesca de camarões nas regiões Sudeste e Sul do Brasil (1965-1999). Atlântica, v.24, p.103-116, 2002.
LAST, P.R.; STEVENS, J.D. Sharks and rays of Australia. Clayton: CSIRO, 1994. 513p.

LESSA, R.P.; VOOREM, C.M; LAHAYE, J. Desenvolvimento e ciclo sexual das fêmeas, migrações e fecundidade da viola Rhinobatos horkelli (Müller \& Henle, 1841) do sul do Brasil. Altântica, v.8, p.5-34, 1986.

MAYES, M.A.; BROOKS, D.R. Cestode parasites of some Venezuelan stingrays. Proc. Biol. Soc. Was., v.93, p.1230-1238, 1980.

MENNI, R.C.; STEHMANN, M.F.W. Distribution, environment and biology of batoid fishes off Argentina, Uruguay and Brazil, a review. Rev. Mus. Arg. Cienc. Nat., v.2, p.69109, 2000.

STEVENS, J.D.; BONFIL, R.; DULVY, N.K.; WALKER, P.A. The effects of fishing on sharks, rays and chimaeras (Chondrichthyans), and the implications for marine ecossystems. ICES (Int. Counc. Explor. Sea) J. Mar. Sci., v.57, p.476494, 2000.

VOOREN, C.M.; KLIPPEL, S. Ações para a conservação de tubarões e raias no Brasil. Porto Alegre: IGARÉ, 2005. 262p.

VOOREN, C.M.; LAMÓNACA, A.F. Rhinoptera brasiliensis. In: IUCN red list of threatened species. Version 2013.1. Available in: <www.iucnredlist.org>. Acessed: 09 July 2013. 